\title{
Detection of drug-resistance genes using single bronchoscopy biopsy specimens
}

\author{
AURELIE TRUSSARDI-REGNIER ${ }^{1}$, JEAN-MARC MILLOT ${ }^{1}$, MARIE-CLAUDE GORISSE ${ }^{2}$, \\ CHANTAL DELVINCOURT ${ }^{2}$ and ALAIN PREVOST ${ }^{2}$ \\ ${ }^{1}$ Unité MéDIAN UMR CNRS 6142, IFR53 Biomolécules, UFR de Pharmacie, 1 rue du M ${ }^{\text {al }}$ Juin, 51096 Reims; \\ ${ }^{2}$ Institut Jean Godinot, 1 rue du $\mathrm{G}^{\mathrm{al}}$ Koenig, 51056 Reims cedex, France
}

Accepted March 12, 2007; Accepted April 30, 2007

\begin{abstract}
Expression of three major resistance genes MDR1, MRP1 and LRP was investigated in small cell lung cancer, non-small cell lung cancer and metastasis. Single biopsies of bronchoscopy from 73 patients were performed to investigate expression of these three resistance genes by reverse transcriptase-polymerase chain reaction. Relations between gene expression and patient age, smoking status, histology, and chemotherapy were evaluated. A more frequent expression of MDR1 (77 versus 66\%), MRP1 (91 versus 72\%) and LRP (77 versus $63 \%$ ) genes was detected in the malignant biopsies than in the non-malignant, respectively. In the metastasis biopsies, expression of these genes was markedly increased. No significant difference was observed between specimens before and after chemotherapy. Biopsies from progressing cancer showed higher MDR1, MRP1 and LRP gene expression. In conclusion, these data reveal a major role of MRP1 in intrinsic resistance and the high gene expression of MDR1 and MRP1 in relapsed diseases.
\end{abstract}

\section{Introduction}

The major problem in lung cancer chemotherapy is the emergence of inherent and acquired drug-resistance which is considered as the main cause of failure of the treatment. Chemoresistance is believed to be caused partly by cellular drug-resistance mechanisms. In fact, the role of each form of multidrug-resistance to lung cancer appears complex and remains inaptly described (1). An important type of resistance is the multidrug-resistance (MDR) which is associated with an altered influx and/or efflux of drugs. Multidrug-resistance is generally caused by a $170-\mathrm{kDa} \mathrm{P}-$ glycoprotein (P-gp), encoded by the MDR1 gene, which is an

Correspondence to: Dr Aurélie Trussardi-Regnier, Université de Reims, Champagne-Ardenne, UFR Pharmacie, Unité MéDIAN UMR CNRS 6142, 1 rue du Mal Juin, 51096 Reims cedex, France E-mail: aurelie.trussardi@univ-reims.fr

Key words: lung cancer, biopsies, MDR1, MRP1 and LRP gene expression, multidrug-resistance, RT-PCR
ATP-binding cassette (ABC) transporter located in the plasma membrane. Aside from P-gp, other resistance-related proteins are defined in lung cancer: the multidrug-resistanceassociated protein (MRP1) and the lung-resistance protein (LRP) encoded by the MRP1 and LRP genes, respectively (2). Like P-gp, MRP1 is a $190-k D a$ transmembrane protein, classified into the ABC superfamily of transport proteins. The $110-\mathrm{kDa}$ LRP is located in the cytoplasm and nuclear membrane and is similar to vault proteins (3). In lung cancer cell culture, overexpression of the MDR1, MRP1 or LRP gene is frequently associated with decreased drug accumulation due to enhanced drug efflux and then with multidrugresistance (4-7). For clinical lung cancers, the relationship between overexpression of the MDR1, MRP1 or LRP gene and chemoresistance remains unclear (1,8-10).

In this report, mRNA expression levels of the chemoresistance genes were analyzed from bronchial biopsies. First, the expression of these genes was compared according to the histological type of each biopsy such as non-malignant, metastatic, small cell lung cancer (SCLC) or non-small cell lung cancer (NSCLC). Secondly, gene expression was also analyzed in relation to the clinical outcome of each patient: initial diagnostic, stabilized or progressive cancer.

\section{Materials and methods}

Patients. Seventy-three patients were admitted to this study. Each biopsy was diagnostically analysed by the cytoanatomo pathology laboratory. Then gene expression was analysed by RT-PCR. The mean age of patients (52 male/11 female) was 60.7 years (range $32-75$ ). The morphological classification of the carcinomas was conducted according to the WHO specifications. Of the 73 biopsies, 22 were neoplastic, 2 were SCLC, 13 were NSCLC and 7 were bronchial metastatic malignancies (metastatic biopsies) and 51 showed no neoplastic pattern (benign or non-malignant biopsies). All patients were staged at the time of their biopsy according to the guidelines of the American Joint Committee on Cancer. Twenty-nine patients had been treated by polychemotherapy (CDDP, VP16 and/or doxorubicin). Parameters are described in more detail in Table I.

Control cell lines. The human NSCLC line A549 (ATCCCCL.185) $(11,12)$ and the human KB-A1 cell line (with a 
270-fold MDR1 gene expression compared to KB-3-1) $(13,14)$ were grown in RPMI-1640 with Glutamax (Gibco-BRL, France) containing $10 \%$ fetal calf serum (FCS, Gibco-BRL) at $37^{\circ} \mathrm{C}$ and in a $5 \% \mathrm{CO}_{2}$ humidified atmosphere.

RT-PCR analysis. All biopsies were freshly frozen, ground in nitrogen, and next the powdered samples were transferred to TriReagent $^{\mathrm{TM}}$ (Sigma Chemical Co., St. Louis, MO, USA). Total cellular RNA was prepared using the guanidine isothiocyanate/acid/phenol method $(15,16)$. MDR1, MRP1, LRP and $\beta_{2}$ microglobulin $\left(\beta_{2} \mathrm{~m}\right)$ transcripts were analysed by semi-quantitative reverse transcription-polymerase chain reaction (RT-PCR) using the following gene-specific oligonucleotide primers: MDR1 forward primer: 5'-CCCAT CATTGCAATAGCAGG-3', MDR1 reverse primer: 5'-GT TCAAACTTCTGCTCCTGA-3', MRP1 forward primer: 5'TCTCTCCCGACATGACCGAGG-3', MRP1 reverse primer: 5'-CCAGGAATATGCCCCGACTTC-3', LRP forward primer: 5'-TTCTGGATTTGGTGGACGC-3', LRP reverse primer: 5'-ACTTCTCTCCCTTGACCAC-3', $\beta_{2} \mathrm{~m}$ forward primer: 5'-ACCCCCACTGAAAAAGATGA-3', $\beta_{2}$ m reverse primer: 5'-ATCTTCAAACCTCCATGATG-3' (Eurogentec, Seraing, Belgium). The $\beta_{2} \mathrm{~m}$ gene was used as a PCR internal control.

In brief, RT was performed using $1 \mu \mathrm{g}$ of total RNA. Total RNA was reverse-transcribed using Moloney Murine Leukemia Virus reverse transcriptase (M-MLV reverse transcriptase; Gibco-BRL), according to the manufacturer's instructions. Aliquots representing $1 / 25$ of the cDNA template were diluted to $100 \mu 1$ in DNA polymerase buffer containing $1.7 \mathrm{mM} \mathrm{MgCl}_{2}, 0.25 \mathrm{mM} \mathrm{dNTP}, 0.5 \mu \mathrm{M}$ and $1 \mu \mathrm{M}$ of primers MDRl and $\beta_{2} \mathrm{~m}$ respectively, and $2.5 \mathrm{U}$ of DNA polymerase (Goldstar; Eurogentec). The MDRl PCR conditions were 35 cycles at $94^{\circ} \mathrm{C}$ for $50 \mathrm{sec}, 57^{\circ} \mathrm{C}$ for $50 \mathrm{sec}$ and $72^{\circ} \mathrm{C}$ for $20 \mathrm{sec}$. For the MRP1 PCR, the same concentration of cDNA was diluted to $100 \mu 1$ in DNA polymerase buffer containing $1.5 \mathrm{mM} \mathrm{MgCl}_{2}, 0.25 \mathrm{mM} \mathrm{dNTP}$, $0.6 \mu \mathrm{M}$ and $0.3 \mu \mathrm{M}$ of primers MRP1 and $\beta_{2} \mathrm{~m}$ respectively and $1.5 \mathrm{U}$ of DNA polymerase. The MRP1 PCR conditions were 32 cycles at $94^{\circ} \mathrm{C}$ for $45 \mathrm{sec}, 61^{\circ} \mathrm{C}$ for $90 \mathrm{sec}$ and $72^{\circ} \mathrm{C}$ for $90 \mathrm{sec}$. The LRP PCR was realized in the same buffer as MRP1 PCR, except the LRP and $\beta_{2} \mathrm{~m}$ primers, which were used at $0.75 \mu \mathrm{M}$ and $0.5 \mu \mathrm{M}$ respectively. The LRP PCR conditions were 32 cycles at $94^{\circ} \mathrm{C}$ for $1 \mathrm{~min}, 58^{\circ} \mathrm{C}$ for $3 \mathrm{~min}$ and $72^{\circ} \mathrm{C}$ for $3 \mathrm{~min}$. All PCR cycles were preceded by 1 cycle at $94^{\circ} \mathrm{C}$ for $3 \mathrm{~min}$ and terminated by 1 cycle at $72^{\circ} \mathrm{C}$ for $10 \mathrm{~min}$.

The target (MDR1, MRP1 or LRP) and control $\left(\aleph_{2} \mathrm{~m}\right)$ gene sequences were coamplified in the same reaction. The PCR conditions were determined to stay in linear conditions. Following PCR, aliquots $(20 \mu \mathrm{l})$ were subjected to electrophoresis of $2 \%$ agarose gel (Gibco-BRL) and bands were visualised by UV transillumination using ethidium bromide (BET, Gibco-BRL) staining prior to photography.

Densitometry was performed using an Imager Soft 1D \& 2D ${ }^{\mathrm{TM}}$ (Appligen Oncor, France) and results were expressed in arbitrary units (AU). To ensure the fidelity of mRNA extraction and reverse transcription for each cDNA sample, all samples were subjected to PCR coamplification with oligonucleotide primers specific for the constitutively expressed gene $\beta_{2}$ microglobulin $\left(\beta_{2} \mathrm{~m}\right)$ and were normalized.

All amplifications of cDNA of the biopsies and cDNA of the internal standards (A549 and KB-A1) were realized in the same way. Indeed, to avoid any intervariation between the experiments, each ratio was divided by the ratio of a PCR internal standard, which was defined as RT-PCR amplification of MRP1 and LRP expression in A549 or MDR1 expression in KB-A1.

Cellular control. Biopsies were spotted on DNase/RNase free slides. After drying, slides were colored by classical May-Grünwald-Giemsa and the cancer cell proportion was estimated.

Statistical analysis. The series of gene expression were compared by the non-parametric Mann-Whitney U test using the Statistica software (Statsoft, France). The gene expression results did not represent a normal population, therefore the results were represented as the minima, $1^{\text {st }}$ quartile, median, $3^{\text {rd }}$ quartile and maxima.

\section{Results}

MDR1, MRPl and LRP gene expression. All analyzed malignant biopsies contained $80-95 \%$ cancer cells. The variations in the expression of three resistance genes are given in Table I. MDR1, MRP1 or LRP mRNA levels were standardized by the $\beta_{2}$ microglobulin expression (see Materials and methods). To increase reproducibility, gene expression of human biopsies was normalized using the MDR1, MRP or LRP expression of reference cell lines A549 and KB-1A.

Most of the resistance gene expression in the bronchial biopsies was largely lower than in the reference cell lines (Table I). In some biopsies, resistance gene expression was lower than the quantification threshold and was equal to zero. The MDR1 gene was expressed in 51 out of 73 cases (range: 0.01-1.16). MRP1 gene expression was observed in 57 out of 73 cases (range: 0.01-0.45). LRP gene expression was detected in 49 out of 73 cases (range: 0.01-0.52). In addition, some biopsies showed exalted values leading to an abnormal distribution of resistance gene expression. These distributions were represented by extreme values, $1^{\text {st }}$ and $3^{\text {rd }}$ quartile and median.

In the bronchial biopsies, no significant difference in resistance gene expression was found in relation to factors such as age, gender or AJCC classification. In addition, resistance gene expression was not significantly different in the tissues from non-smokers or smokers (Table I).

MDR1 gene expression was detected in 66\% (34/51) and $77 \%(17 / 22)$ of non-malignant and malignant biopsies respectively. For MRP1, 72\% (37/51) of non-malignant versus 91\% (20/22) of malignant biopsies showed a quantifiable expression. Moreover, expression levels were significantly higher in malignant biopsies for both MDR1 $(\mathrm{p}<0.05)$ and MRP1 genes $(\mathrm{p}<0.01)$ (Table I). Sixty-three percent of nonmalignant biopsies showed LRP expression compared to $77 \%$ of malignant biopsies. However, these LRP expression levels were equivalent for non-malignant and malignant biopsies (Table I). 
Table I. Characteristics and clinical outcome of 73 patients.

\begin{tabular}{|c|c|c|c|c|}
\hline \multirow[t]{2}{*}{ Factors } & \multirow[t]{2}{*}{ No. of patients } & \multicolumn{3}{|c|}{ Gene expression (median, AU) } \\
\hline & & MDR1 & MRP1 & LRP \\
\hline \multicolumn{5}{|l|}{ Mean age (years) } \\
\hline $60.7 \pm 10.5$ & 73 & & & \\
\hline \multicolumn{5}{|l|}{ Age } \\
\hline$\leq 60$ & 25 & 0.03 & 0.03 & 0.04 \\
\hline$>60$ & 48 & 0.03 & 0.04 & 0.02 \\
\hline \multicolumn{5}{|l|}{ Gender } \\
\hline Male & 52 & 0.03 & 0.04 & 0.02 \\
\hline Female & 21 & 0.04 & 0.03 & 0.03 \\
\hline \multicolumn{5}{|l|}{ Tobacco $^{\mathrm{a}}$} \\
\hline Smokers & 26 & 0.01 & 0.02 & 0.01 \\
\hline Non-smokers & 42 & 0.04 & 0.04 & 0.04 \\
\hline \multicolumn{5}{|l|}{ Histology of biopsy } \\
\hline Non-malignant (benign) & 51 & $0.03^{\mathrm{d}}$ & $0.02^{\mathrm{e}}$ & 0.02 \\
\hline Malignant & 22 & $0.05^{\mathrm{d}}$ & $0.08^{\mathrm{e}}$ & 0.03 \\
\hline \multicolumn{5}{|l|}{ AJCC classification ${ }^{b}$} \\
\hline IIA/IIB & 3 & 0.04 & 0.28 & 0.05 \\
\hline IIIA/IIIB & 7 & 0.12 & 0.02 & 0.02 \\
\hline IV & 5 & 0.04 & 0.08 & 0.13 \\
\hline Unclassified & 7 & 0.11 & 0.14 & 0.01 \\
\hline \multicolumn{5}{|l|}{ Therapeutic } \\
\hline No chemotherapy/no radiotherapy & 43 & 0.03 & 0.04 & 0.03 \\
\hline Chemotherapy & 22 & 0.03 & 0.04 & 0.02 \\
\hline Chemotherapy/radiotherapy & 7 & 0.05 & 0.14 & 0.05 \\
\hline Radiotherapy $^{\mathrm{c}}$ & 1 & 0.01 & 0.01 & 0.06 \\
\hline \multicolumn{5}{|l|}{ Clinical outcome $\mathrm{e}^{\mathrm{b}}$} \\
\hline Initial state & 5 & 0.00 & 0.08 & 0.00 \\
\hline Regression/stabilization & 4 & 0.03 & 0.06 & 0.02 \\
\hline Progression & 13 & 0.11 & 0.16 & 0.08 \\
\hline \multicolumn{5}{|l|}{ Positive control } \\
\hline $\begin{array}{l}\text { KB-A1 (dilution of KB-A1 ARNm } \\
\text { by KB-3-1 ARNm, d=1/10, }(13,14)\end{array}$ & & 0.72 & - & - \\
\hline A549WT & & - & 0.57 & 1.06 \\
\hline
\end{tabular}

All results are expressed in arbitrary units (AU) as described in Materials and methods. Values represent the median of the population. ${ }^{\mathrm{a}}$ Five patients were not classified, and cigarette consumption could not be precisely determined. Smokers had a daily consumption of at least 20

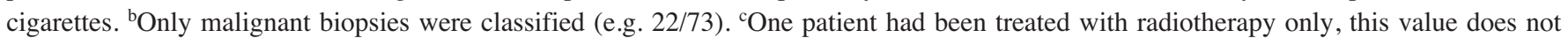
represent the median but the exact value. ${ }^{\mathrm{d}} \mathrm{p}<0.05,{ }^{\mathrm{e}} \mathrm{p}<0.01$.

Influence of histology on gene expression. Resistance gene expression was significantly higher in malignant biopsies than non-malignant ones (Table I). Expression levels were compared as a function of pathological subtypes of lung cancer (Fig. 1). The expression of the three genes in the metastatic biopsies was higher than expression in nonmalignant biopsies for MDR1 $(\mathrm{p}<0.05)$, MRP1 $(\mathrm{p}<0.05)$ and LRP ( $<<0.05)$. Moreover, MRP1 expression was significantly higher in metastatic, SCLC and NSCLC histological subtypes as compared to non-malignant biopsies $(\mathrm{p}<0.05)$ (Fig. 1). In addition, no significant difference was observed among SCLC, NSCLC and non-malignant biopsies for MDR1 and LRP gene expression.

Influence of chemotherapy on gene expression. Among 73 analyzed biopsies, 29 patients had been treated by polychemotherapy (CDDP, VP16 and/or doxorubicin). No significant difference in MDR1, MRP1 and LRP gene expression was observed between biopsies either from treated or untreated patients. It is worth mentioning that NSCLC biopsies showed slightly higher MRP1 gene expression in chemotherapy-treated patients compared to untreated patients 
Table II. Median of MDR1, MRP1 and LRP gene expression in biopsies before or after chemotherapy (AU).

\begin{tabular}{|c|c|c|c|c|c|c|}
\hline & \multicolumn{2}{|c|}{ MDR1 } & \multicolumn{2}{|c|}{ MRP1 } & \multicolumn{2}{|c|}{ LRP } \\
\hline & \multicolumn{2}{|c|}{ Chemotherapy } & \multicolumn{2}{|c|}{ Chemotherapy } & \multicolumn{2}{|c|}{ Chemotherapy } \\
\hline & - & + & - & + & - & + \\
\hline Non-malignant & $0.02(32)$ & 0.03 (19) & $0.02(32)$ & $0.02(19)$ & $0.03(32)$ & $0.02(19)$ \\
\hline Metastasis & $0.11(5)$ & $0.31(2)$ & $0.16(5)$ & $0.09(2)$ & $0.15(5)$ & $0.08(2)$ \\
\hline NSCLC & $0.04(7)$ & $0.03(6)$ & $0.02(7)$ & $0.08(6)$ & $0.01(7)$ & $0.02(6)$ \\
\hline SCLC & - & $0.13(2)$ & - & $0.22(2)$ & - & $0.13(2)$ \\
\hline
\end{tabular}

Number between brackets is the number of patients.
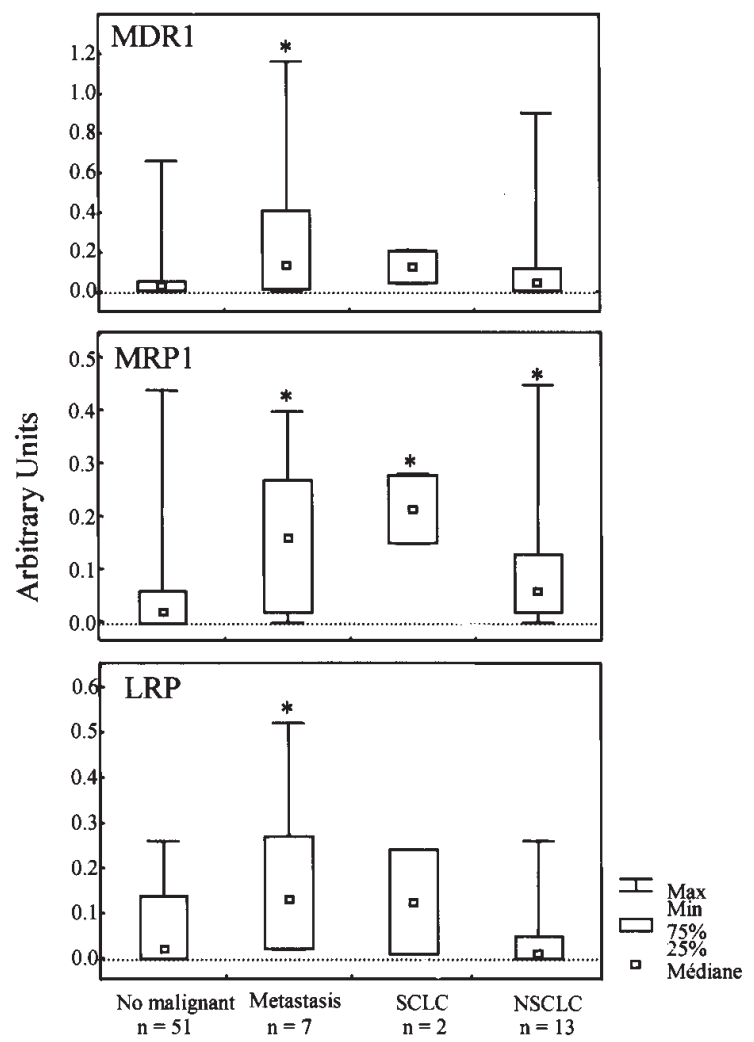

Figure 1. Influence of the histological type on MDR1, MRP1, and LRP gene expression. Boxes of the box-and-whisker plots extend from the $25^{\text {th }}$ percentile to the $75^{\text {th }}$ percentile, with a small square at the median $\left(50^{\text {th }}\right.$ percentile). Whiskers depict the range (min-max) of the data. "Results are significant; $\mathrm{p}<0.05$.

(0.08 versus $0.02, \mathrm{p}=0.11)$ (Table II). The increase of resistance gene expression previously reported (Fig. 1) in metastatic biopsies was equal for treated and untreated patients (Table II). For metastatic biopsies, an intrinsic resistance expression was observed without chemotherapy. The expression level was not dependent on chemotherapy treatment.

Resistance gene expression as a prognostic factor. Malignant biopsies were classified as i) diagnostic samples (initial state), ii) samples from stabilized cancers and iii) samples of progressive cancers. According to these clinical states, medians
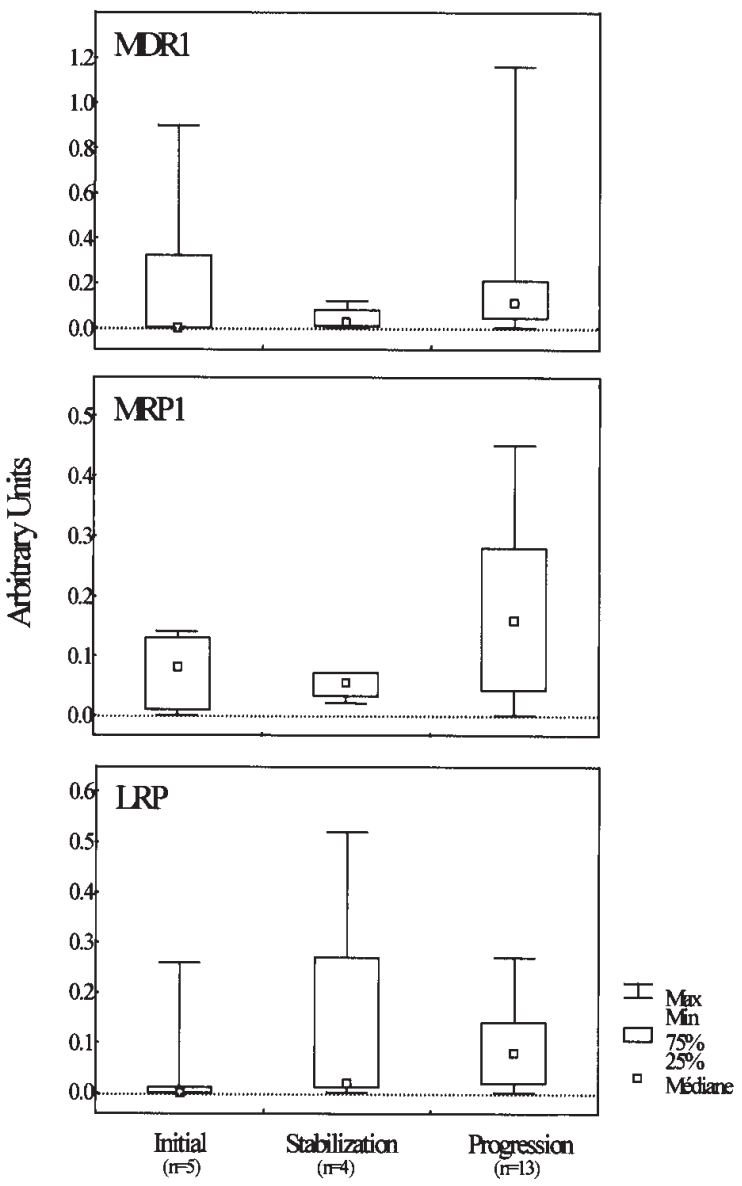

Figure 2. Influence of clinical outcome on MDR1, MRP1, and LRP gene expression. Boxes of the box-and-whisker plots extend from the $25^{\text {th }}$ percentile to the $75^{\text {th }}$ percentile, with a small square at the median $\left(50^{\text {th }}\right.$ percentile). Whiskers depict the range (min-max) of the data.

of resistance gene expression were not equivalent. MDR1, MRP1 and LRP gene expression from progressing cancers increased compared to expression from both initial and stabilized cancers (Table I and Fig. 2).

It was observed that the LRP gene shows a high expression dispersion among biopsies classified as stabilized cancers. Thus, the discrimination between groups of stabilized and progressing cancers was studied through MDR1 and MRP1 gene expression (Fig. 3). Each of the stabilized cancers are represented in Fig. 3A. These cancers showed 
A

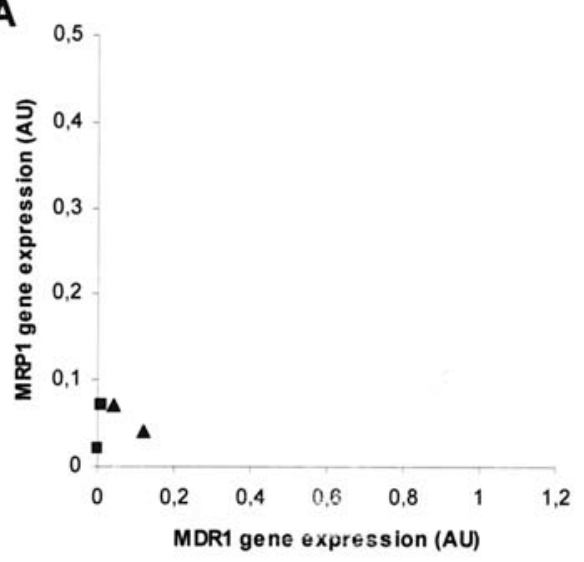

B

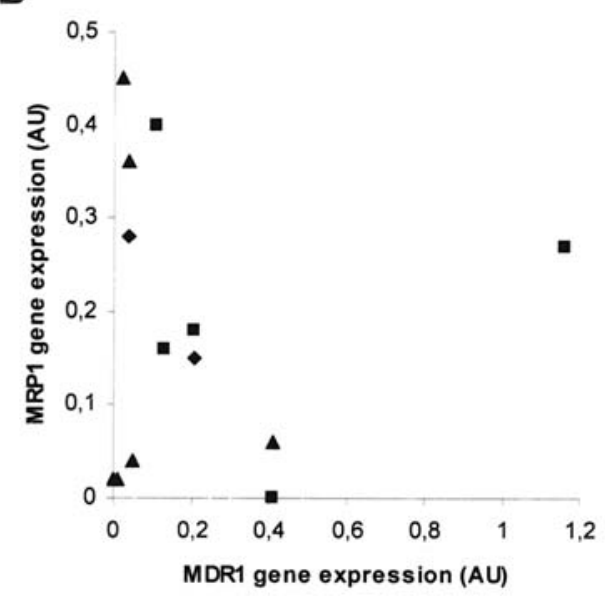

Figure 3. Relation between MDR1 and MRP1 gene expression, histology and the clinical outcome. (A) Stabilized cancer: (ם) biopsies from stabilized metastatic cancer; ( $\mathbf{\Delta})$ biopsies from stabilized NSCLC. (B) Progressing cancer: ( $\square$ ) biopsies from progressing metastatic cancer; $(\diamond)$ biopsies from progressing SCLC; and ( $\mathbf{\Delta})$ biopsies from progressing NSCLC.

expression levels <0.15 AU and 0.10 AU threshold, for MDR1 and MRP1, respectively. No difference was shown among biopsies from stabilized metastatic cancers and stabilized NSCLC.

Most of the progressing cancers (Fig. 3B) showed expression levels >0.15 AU and/or 0.10 AU for MDR1 and MRP1, respectively. All progressing metastasis and SCLC presented increased gene expression. In addition, some of the progressing NSCLC showed gene expression lower than these expression thresholds.

In conclusion, gene expression of MDR 1 and MRP1 characterized a progressing status of metastasis biopsies.

\section{Discussion}

The response of lung cancer to chemotherapy treatment is characterized by multifactorial multidrug-resistance that may be either acquired (SCLC) or intrinsic (NSCLC) (1). This response results in treatment failure and death within 2 years of diagnosis in the majority of cases. However, there is increasing evidence that a wide variety of drug-resistance mechanisms operates through the development of clinically relevant drug-resistance (MDR1, MRP1, and LRP) gene expression (1,4,17-19).

In this study, we performed a semi-quantitative RT-PCR to analyze expression profiles of three well-known drugresistance genes, i.e., MDR1, MRP1, and LRP of bronchial biopsies. These expression levels were analyzed in relation to clinicopathological features of each patient. Moreover, cross correlations between MDR1, MRP1 and LRP gene expression described a correlation between LRP and MRP1 expression.

As previously demonstrated (20), we report here that no significant difference occured in MDR1, MRP1, and LRP gene expression, as a function of prognostic factors (age, gender, AJCC classification) of each patient. Between smokers and non-smokers, the expression levels of the three resistance genes were compared and no significant difference was observed. A slight correlation of borderline significance was demonstrated between LRP gene expression and the smoking habits of patients (20). Although these results depended on tumor histology, another report has shown that P-gp was increased in the tumors of smokers (21).

We demonstrated here that $>60 \%$ of biopsy specimens expressed at least one of the three resistance genes. Resistance gene expression was detected more frequently in tumors than in normal tissues (MDR1: 77 versus 66\%, MRP1: 91 versus $72 \%$ and LRP: 77 versus $63 \%$ ). As previously reported, gene expression was dependent on the histological subtype $(17,22-24)$. An increase in different genetic markers (P-gp, ErbB-2, P53, Bcl-2) was previously observed in pulmonary metastases (22). In this study, we demonstrated an increase in expression of three resistance genes in metastatic biopsies. This simultaneous expression in metastases could explain many therapeutic failures due to intrinsic resistance of metastases.

In NSCLC biopsies, the expression level of MRP1 was higher than in normal tissues. In these samples, neither MDR1 nor LRP expression was significantly modulated. Similar results were shown in SCLC biopsies where the MRP1 gene seemed more involved than the MDR1 and/or LRP genes, as reported elsewhere (1). Moreover, Campling et al have also shown that MRP protein $(\sim 70 \%)$ was more frequently expressed than P-gp (50-60\%) in clinical samples from SCLC (25). The LRP gene was overexpressed in a subgroup of NSCLC cell lines correlating with resistance against cisplatin (4). In our study, LRP expression was comparable between the normal and the malignant bronchial epithelium.

The relation between the expression of the three genes MDR1, MRP1 and LRP and resistance to chemotherapy has been previously discussed $(17,18,26-28)$. For example, LRP was reported as a predictive marker for treatment response in NSCLC by Harada et al (26). Hsia et al showed that among 50 patients, 27 expressed neither MDR1 nor MRP1 and presented a high response to chemotherapy. In contrast, the patients which expressed at least one of the resistance genes had a weaker response to chemotherapy (29). In our study, the chemotherapy treatment did not modify to a significant degree the MDR1 or LRP gene expression for SCLC or NSCLC. After chemotherapy, MRP1 was not significantly increased in the NSCLC. However, this gene was already 
highly expressed in the NSCLC, which partly explains the intrinsic resistance of these cancers. Moreover, many studies imply both MDR1, MRP1 and/or LRP gene expression in resistance to chemotherapy $(4,26)$. As the phenomenon of resistance is multi-factored, these results could depend on independent analysis of resistance genes. In this study, we also illustrated an increase in MDR 1 and MRP1 gene expression in progressing pathologies. The simultaneous analysis of these two genes would help to establish a clinical outcome. Thus, it could be possible to describe a forecast factor by the analysis of MDR1 and MRP1 gene expression.

Further studies will monitor resistance gene expression during various types of lung cancer chemotherapy. These studies will research the implication of resistance genes and define characteristic resistance gene profiles associated with the clinical outcome.

\section{Acknowledgements}

The authors would like to thank the late Professor J.C. Jardillier for the framing of this study. The authors are grateful to Marie-José Faroux and Alain Kolkés for their excellent technical assistance. This research was supported by grants from 'Association Régionale pour l'Enseignement et la Recherche Scientifique et Technique en ChampagneArdenne' (ARERS, Reims).

\section{References}

1. Scagliotti GV, Novello S and Selvaggi G: Multidrug-resistance in non-small-cell lung cancer. Ann Oncol 10: 583-586, 1999.

2. Volm M and Mattern J: Resistance mechanisms and their regulation in lung cancer. Crit Rev Oncol 7: 227-244, 1996.

3. Scheffer GL, Wijngaard PLJ, Flens MJ, Izquierdo MA, Slovak ML, Pinedo HM, Meijer CJLM, Clevers HC and Scheper RJ: The drug-resistance-related protein LRP is the human major vault protein. Nat Med 1: 578-582, 1995.

4. Berger W, Elbling L and Micksche M: Expression of the major vault protein LRP in human non-small-cell lung cancer cells: activation by short-term exposure to antineoplastic drugs. Int J Cancer 88: 293-300, 2000.

5. Trussardi A, Poitevin G, Gorisse MC, Faroux MJ, Bobichon H, Delvincourt C and Jardillier JC: Sequential overexpression of LRP and MRP but not P-gp 170 in VP16-selected A549 adenocarcinoma cells. Int J Oncol 13: 543-548, 1998.

6. Nicamhlaoibh R, Heenan M, Cleary I, Touhey S, O'Loughlin C, Daly C, Nunez G, Scanlon KJ and Clynes M: Altered expression of mRNAs for apoptosis-modulating proteins in a low level multidrug-resistant variant of a human lung carcinoma cell line that also expresses mdrl mRNA. Int J Cancer 82: 368-376, 1999.

7. Young LC, Campling BG, Cole SPC, Deeley RG and Gerlach JH: Multidrug-resistance proteins MRP3, MRP1, and MRP2 in lung cancer: correlation of protein levels with drug response and messenger RNA levels. Clin Cancer Res 7: 1798-1804, 2001.

8. Dingemans AMC, Van Ark-Otte J, Van Der Valk P, Apolinario RM, Scheper RJ, Postmus PE and Giaccone G: Expression of the human major vault protein LRP in human lung cancer samples and normal lung tissues. Ann Oncol 7: 625-630, 1996.

9. Kickhoefer VA, Rajavel KS, Scheffer GL, Dalton WS, Scheper RJ and Rome LH: Vaults are up-regulated in multidrug-resistant cancer cell lines. J Biol Chem 27: 8971-8974, 1998.

10. Nishio K, Nakamura T, Koh Y, Suzuki T, Fukumoto H and Saijo N: Drug-resistance in lung cancer. Curr Opin Oncol 11: $109-115,1999$.

11. Giard D, Aaronson SA, Todaro GJ, Arnstein P, Kersey JH, Dosik H and Parks WP: In vitro cultivation of human tumors: establishment of cell lines derived a series of solid tumors. J Natl Cancer Inst 51: 1417-1423, 1973.
12. Lierber M, Smith B, Szakal A, Nelson-Rees W and Todaro G: A continuous tumor-cell line from a human lung carcinoma with properties of type II alveolar epithelial cells. Int J Cancer 17: 62-70, 1976.

13. Chevillard S, Pouillart P, Beldjord C, Asselain B, Beuzeboc P, Magdelenat $\mathrm{H}$ and Vielh P: Sequential assessment of multidrugresistance phenotype and measurement of S-phase fraction as predictive markers of breast cancer response to neoadjuvant chemotherapy. Cancer 77: 292-300, 1996.

14. Chevillard S, Vielh Ph, Validire P, Marie JP, Faussat AM, Barbu V, Bayle C, Benard J, Bonnal C, Boutonnat J, Calvo F, Charrier J, Clary A, Colosetti P, Danel-Moore L, Decremoux P, Delvincourt C, Finat-Duclos F, Genne Ph, Kataki A, Kouyoumdjian JC, Lacave R, Maugard C, Merlin JL, Mousseau M, Pinguet F, Quillien V, Raphael M, Richard B, Verrelle P, and Robert J: French multicentric evaluation of $\operatorname{mdr} 1$ gene expression by RT-PCR in leukemia and solid tumours. Standardization of RT-PCR and preliminary comparisons between RT-PCR and immunohistochemistry in solid tumours. Leukemia 11: 1095-1106, 1997.

15. Chomczynski $\mathrm{P}$ and Sacchi N: Single-step method of RNA isolation by acid guanidinium-thiocyanate-phenol-chloroform extraction. Anal Biochem 162: 156-159, 1987.

16. Chomczynski P: A reagent for the single-step simultaneous isolation of RNA, DNA, proteins from cell and tissue samples. Biotechniques 15: 532-537, 1993.

17. Berger W, Setinek U, Hollaus P, Zidek T, Steiner E, Elbling L, Cantonati H, Attems J, Gsur A and Micksche M: Multidrugresistance markers P-glycoprotein, multidrug-resistance protein 1, and lung resistance protein in non-small cell lung cancer: prognostic implications. J Cancer Res Clin Oncol 131: 355-363, 2005.

18. Chiou JF, Liang JA, Hsu WH, Wang JJ, Ho ST and Kao A: Comparing the relationship of Taxol-based chemotherapy response with P-glycoprotein and lung resistance-related protein expression in non-small cell lung cancer. Lung 181: 267-273, 2003.

19. Volm M, Koomagi R, Mattern J and Efferth T: Protein expression profiles indicative for drug-resistance of non-small cell lung cancer. Br J Cancer 87: 251-257, 2002.

20. Volm M, Mattern J and Koomägi R: Expression of lung resistance-related protein (LRP) in non-small cell lung carcinomas of smokers and non-smokers and its predictive value for doxorubicin resistance. Anticancer Drugs 8: 931-936, 1997.

21. Volm M, Mattern J and Samsel B: Overexpression of P-glycoprotein and glutathione S-transferase-pi in resistant non-small cell lung carcinomas of smokers. Br J Cancer 64: 700-704, 1991.

22. Ferrari S, Bertoni F, Zanella L, Setola E, Bacchini P, Alberghini M, Versari M and Bacci G: Evaluation of P-glycoprotein, HER2/ErbB-2, p53, and Bcl-2 in primary tumor and metachronous lung metastases in patients with high-grade osteosarcoma. Cancer 100: 1936-1942, 2004.

23. Okada D, Kawamoto M, Koizumi K, Tanaka S and Fukuda Y: Immunohistochemical study of the expression of drug-resistant proteins in large cell neuroendocrine carcinoma of the lung. Jpn J Thorac Cardiovasc Surg 51: 272-276, 2003.

24. Rybarova S, Hajdukova M, Hodorova I, Kocisova M, Boor A, Brabencova E, Kasan P, Biros E, Mojzis J and Mirossay L: Expression of the multidrug-resistance-associated protein 1 (MRP1) and the lung resistance-related protein (LRP) in human lung cancer. Neoplasma 51: 169-174, 2004.

25. Campling BG, Young LC, Baer KA, Lam YM, Deeley RG, Cole SP and Gerlach JH: Expression of the MRP and MDR1 multidrug-resistance genes in small cell lung cancer. Clin Cancer Res 3: 115-122, 1997.

26. Harada T, Ogura S, Yamazaki K, Kinoshita I, Itoh T, Isobe H, Yamashiro K, Dosaka-Akita $\mathrm{H}$ and Nishimura M: Predictive value of expression of P53, Bcl-2 and lung resistance-related protein for response to chemotherapy in non-small cell lung cancers. Cancer Sci 94: 394-399, 2003.

27. Steiner E, Holzmann K, Elbling L, Micksche M and Berger W: Cellular functions of vaults and their involvement in multidrugresistance. Curr Drug Targets 7: 923-934, 2006.

28. Perez-Tomas R: Multidrug-resistance: retrospect and prospects in anti-cancer drug treatment. Curr Med Chem 13: 1859-1876, 2006.

29. Hsia TC, Lin CC, Wang JJ, Ho ST and Kao A: Relationship between chemotherapy response of small cell lung cancer and $\mathrm{P}$-glycoprotein or multidrug-resistance-related protein expression. Lung 180: 173-179, 2002. 